\title{
The Right Hon. Thomas Henry Huxley.
}

The Journal of our Association cannot be allowed to appear without a few words in memory of our first President, the great naturalist and leader of Science, whom we all mourn.

Huxley's studies in marine biology, and his position as a Government official, as well as his keen, practical common-sense, made his selection as a member of two Government Commissions on Fisheries (in 1863 and again in 1883) very appropriate. He did valuable work on those Commissions, and in 1881 was appointed, by Sir William Harcourt, to be Inspector of Salmon Fisheries. In 1883 he took an active part in the work of the International Fisheries Exhibition, and emphasized in an address given there, the fact that, whilst civilized man had brought all the resources of science to bear on the "harvest of the land," little or nothing had been done in the same spirit for the "harvest of the sea."

When, in 1884, the movement was set on foot for the foundation of the Marine Biological Association, Huxley, as President of the Royal Society, took the chair at the important meeting in the rooms of that Society, at which the Association was founded, and subsequently he consented to be the first President of the Association. With that thoroughness and conscientiousness which marked all his work, our President, though no longer in full health and vigour, attended regularly the meetings of the Council, and gave the most careful attention to the very onerous business which had to be discharged in the early days of the organization of the Association, and the building of the Plymouth Laboratory. His advice and direction were always valued in the highest degree by the Council, and his genial presence at our meetings was greatly appreciated, especially in view of the fact that he travelled from Eastbourne to London, in order to assist us. After seven years, when the laboratory was in full working order, he asked us, on the ground of his delicate health, to accept his resignation of the presidency, which, reluctantly, we did.

The successful launching of our Association, the assistance given to it by the Government, by the City Companies, and by other public bodies, are mainly due to the one fact, that we had at our head a man so profoundly trusted as was Professor Huxley.

NEW SERIEs. - VOL. IV. No. 1. 
The brief description of the purpose of the Association, adopted and circulated by its authority, was due to him, and runs as follows: "To establish and maintain Laboratories on the coast of the United Kingdom, where accurate researches may be carried on, leading to the improvement of Zoological and Botanical Science, and to an increase of our knowledge as regards the food, life-conditions, and habits, of British food-fishes and molluses."

This is not the place to speak of the manifold labours of our late President in other fields. Our Association is but one of a hundred useful works in which his hand can be traced. But it is, above all, as the man who, without sacrificing the respect of his opponents, has gained for scientific thought a freedom and a hearing, such as were absolutely denied to it in his younger days, that Englishmen must ever remember Huxley with gratitude. Whenever we consult his writings, whether in the laboratory, or in the study-we recognise his power, his extraordinary range and accuracy of knowledge, and his charming style: but we must not think of him either as merely a zoologist, or, as merely an essayist, but as a man who most strenuously, and successfully, fought for the supremacy of Science.

E. Ray Lankester.

July, 1895. 